\title{
Globális kihívások a mezőgazdaságban
}

\author{
D. FRÓNA
}

Debreceni Egyetem, Gazdaságtudományi Kar, Agrárközgazdasági Tanszék, frona.daniel@econ.unideb.hu

Absztrakt. Jelentős globális kihívásokkal kell szembenézni napjainkban a mezőgazdaság tekintetében. A természeti erőforrásokkal megfelelően kell gazdálkodni, hogy idő előtti kimerülésüket elkerüljük (erőforrás-gazdálkodás). Az embernek szüksége van a természeti eröforrásokra, -fémre, ásványi anyagra, fára, termöföldre, élelmiszerre, levegöre és vízre -nem túlozva ezek az élet nélkülözhetetlen feltételei. A probléma, hogy az emberiség nagyobb mértékben éli fel ezeket az erőforrásokat, mint ahogyan az természetes módján újratermelődne. A biológiai diverzitás és az ökoszisztéma megörzéséhez és fenntartásához a növény- és állatfajok védelme elkerülhetetlen. Ha elpusztítjuk környezetünket, akkor a jövő helyzete, az emberiség léte kerül veszélybe. Egyes elörejelzések szerint 2050-ben a mai eröforrás kitermelés ötszörösét fogjuk elérni. Egyes ökoszisztémák 60\%-ára igaz, hogy az erőforrásait már jelenleg is túlzott mértékben használjuk ki, gondoljunk csak a halállományra vagy a mértéktelen esőerdei fakitermelésre, ami köztudottan baljós feltevéseket vetít elöre a levegöszennyezésre nézve. 2050-re az emberiség 30\%-os növekedését prognosztizálják a kutatók, ami 9 milliárd embert jelent. A népesség több mint 70\%a fog városban lakni, ami újabb területeket fog elvonni a természetes élőhelyekből. A világnépesség növekedésével az étrendben is jelentős változás fog bekövetkezni, elsősorban a magas hozzáadott-értékủ élelmiszerek irányába tolódik el a fogyasztási szerkezet. Ez a növekedés azt eredményezi, hogy az állattenyésztés takarmányigénye nö, ami földhasználatban indukál változást. Az elöttünk álló út egyértelmú és világos, sokkal hatékonyabban kell gazdálkodnunk a természeti erőforrásainkkal. Továbbá ezeket úgy kell kitermelnünk/elóállítanunk, hogy a környezetet tovább ne romboljuk, a jelenlegi állapotát ne rontsuk. A globálisan követendố cél az lenne, hogy mind kevesebb erőforrás felhasználásával több értéket állítsunk elö. Már a nyersanyagok kitermelésétől kezdve óvni kell a környezetet, és ezt folytatni az eloóllított termékek felhasználásán keresztül egészen addig, amíg esetlegesen hulladék nem keletkezik belóle. Itt kerül elôtérbe a folyamatos terméktervezés és - fejlesztés, valamint a pazarló eljárások visszaszorítása az anyagtakarékosság visszaszorításával. A jelenlegi gazdaságnak törekednie kell a fenntartható jövő elérésére.

Abstract. At the present time, in contrast with the past, global challenges can be found in agriculture as well. We must act with the care of our natural resources to prevent the depletion of them (resource management). The humanity requires the natural resources (metal, metal, minerals, wood, soil, food, air and water), without any exaggerations human life can depend on them. The crucial problem is that humanity has a greater consumption of these resources than it would naturally replicate themselves. To conserve and maintain the biodiversity and ecosystem the animal and plant protection is inevitable. If we destroy our environment, the situation of the future, the existence of mankind is endangered. According to some relevant forecasts by 2050 humanity will use resources five times more than now. It is true for $60 \%$ of some ecosystems that the resources are being exploited too much nowadays, just think about the remained fish stocks or the excessive rainforest logging, which predicts catastrophic assumptions about the air pollution. Researchers say by 2050 the population will increase by 30\% which means 9 billion people. $70 \%$ of the population will live in urban area that results the loss of more and new areas from the remaining natural habitats. With the rise of the population, a significant change in the diet will also occur, the consumption structure is shifting primarily towards to the high added-value foods. This increase leads to a growing 
demand for livestock feed, which indicates changings in land use. The way ahead is clear and unambiguous, we have to manage our natural resources more effectively. Furthermore, resources must be extracted/produced in such way that the environment is not further destroyed and not degraded more than the present condition. The global goal would be that to produce more value with less resource usage. The environment has to be protected from the beginning of extraction of raw materials and continue this protection through the consumption of the products. The focus is on the continuous product design and development, as well as to reduce wasteful processes by reducing material savings. The current economy must strive for a more sustainable future.

\section{Bevezetés}

A Földön számos környezeti kihívás mára már globális méretet öltött. A természeti erőforrásokkal megfelelően kell gazdálkodni, hogy idő előtti kimerülésüket elkerüljük (erőforrás-gazdálkodás).

Az embernek szüksége van a természeti erőforrásokra, -fémre, ásványi anyagra, fára, termőföldre, élelmiszerre, levegőre és vízre -nem túlozva ezek, az élet nélkülözhetetlen feltételei. A probléma viszont ott kezdődik, hogy az emberiség nagyobb mértékben éli fel ezeket az erőforrásokat, mint ahogyan az természetes módján újratermelődne. A biológiai diverzitás és az ökoszisztéma megőrzéséhez és fenntartásához a növény- és állatfajok védelme elkerülhetetlen. Ha elpusztítjuk környezetünket, akkor a jövő helyzete, az emberiség léte kerül veszélybe.

Egyes előrejelzések szerint 2050-ben a mai erőforrás kitermelés ötszörösét használnánk fel. A feltételes mód azért volt indokolt, mert valószínűleg erre nem lesz lehetőségünk. Egyes ökoszisztémák 60\%-ára igaz, hogy az erőforrásait már jelenleg is túlzott mértékben használjuk ki, gondoljunk csak a halállományra vagy a mértéktelen esőerdei fakitermelésre, ami köztudottan baljós feltevéseket vetít előre a levegőszennyezésre nézve. Továbbá 2050-re az emberiség 30\%-os növekedését prognosztizálják a kutatók, ami 9 milliárd embert jelent. A népesség több mint 70\%-a fog városban lakni, ami újabb területeket fog elvonni a természetes élóhelyekből [1].

A világnépesség növekedésével az étrendekben kialakult szokás is változni fog. Egyre több lesz az igény a magas hozzáadott-értékű élelmiszerek iránt, az élelmiszerek iránti kereslet 70\%-kal fog nőni. Ez a növekedés azt eredményezi, hogy az állattenyésztés takarmányigénye nő, ami földhasználatban indukál változást [2].

Az előttünk álló út egyértelmű és világos, sokkal hatékonyabban kell gazdálkodnunk a természeti erőforrásainkkal. Továbbá ezeket úgy kell kitermelnünk/előállítanunk, hogy a környezetet tovább ne romboljuk, a jelenlegi állapotát ne rontsuk még tovább.

A globálisan követendő cél az lenne, hogy mind kevesebb erőforrás felhasználásával több értéket állítsunk elő. Már a nyersanyagok kitermelésétől kezdve óvni kell a környezetet, és ezt folytatni az előállított termékek felhasználásán keresztül egészen addig, amíg esetlegesen hulladék nem keletkezik belőle. Itt kerül előtérbe a folyamatos terméktervezés és - fejlesztés, valamint a pazarló eljárások visszaszorítása az anyagtakarékosság visszaszorításával. A jelenlegi gazdaságnak törekednie kell a fenntartható jövő elérésére.

Mit is jelent a fenntarthatóság? Az ENSZ 1987-ben kiadott jelentése szerint: "a fenntartható fejlődés olyan fejlődés, amely kielégíti a jelen szükségleteit, anélkül, hogy veszélyeztetné a jövő nemzedékek 
esélyét arra, hogy ők is kielégithessék szükségleteiket". A legtöbb megfogalmazás szerint azt, hogy a jelenlegi generációnak oly módon kellene gazdálkodnia erőforrásaival, hogy a jövő nemzedékét ne veszélyeztessék az erőforrások felhasználásával és a környezet elpusztításával. Ebből kiindulva a gazdaságpolitikának is olyan irányt kell vennie, mely előtérbe helyezi a fenntarthatóságot és komolyan figyelembe veszi a természeti környezetet.

\section{Szakirodalmi áttekintés}

\subsection{Globális kihívások}

A 2014. év őszén váratlan olajárzuhanás következett be, amikor is a nyersolaj hordónkénti ára $70 \$$ alatt maradt egészen 2015 elejéig [3]. Az alacsony olajár a kisebb kereslet - köszönhetően a lassú gazdasági növekedésnek és a magasabb felhasználási hatékonyságnak - és a túlkínálat együttes hatásával magyarázható. Ennek további magyarázata, hogy a hagyományos piaci szereplők - például Líbia visszatérése a piacra - mellett erőteljes kibocsátásba kezdett USA és Oroszország is, valamint az OPEC 5 (Irak, Irán, Kuvait, Szaúd-Arábia, Venezuela) országai sem csökkentették a termelést. Ez napi mintegy 2 millió hordónyi túlkínálatot jelentett. Valamint a BRICS országokban kialakult zűrzavar is hozzájárult a 2015-ös árak alakulásához. 2016-ra az érték relatíve kis mértékben emelkedett, 2017-es év végére 60-65\$ között mozgott az ár a Brent adatai alapján. Kína gazdasági növekedése lelassult, de még mindig a világgazdaság hajtómotorja Indiával karöltve. Meg kell említenünk az euró és a dollár kapcsolatát, amely szintén komoly befolyásoló tényező. Az euró-dollár valutaárfolyam a 2017-es év végére 1,25 körül állt egy év közbeni emelkedést követően XE Currency Charts (2017) adatai szerint. Például az EU mezőgazdasági piacára egy ilyen makrogazdasági esemény vegyes hatással lehet.

A világ népességének folyamatos növekedése ösztönzi a keresletet és támogatja a mezőgazdasági termékek magasabb árait. A rövidtávon azonban alacsonyabb gazdasági növekedés várható, ami korlátozza a jövedelem növekedését és így bekorlátozza a növekvő kereslet hatókörét.

A globális kereslet növekedése az előrejlések szerint lassulni fog az előző évtizedhez képest. Az elmúlt évtizedben példa nélküli kereslet volt megfigyelhető a mezőgazdasági termékek iránt [4].

2014 és 2016 közötti időszakban a gabonafélék (búza, kukorica, rizs és stb.) teljes fogyasztása 2,5 milliárd tonnára nőtt a 10 évvel korábbi mennyiséghez képest, ami 2,0 milliárd tonna volt. A baromfifogyasztás 81 millió tonnáról (2004-2006) 113 millió tonnára nőtt, amely 32 millió tonna növekedés egy évtized alatt. Az emberi fogyasztásra szánt halak iránti kereslet is jelentősen nőtt 111 millió tonnáról 149 millió tonnára a vizsgált 10 évben. Az elmúlt tíz évben a mezőgazdasági piacokon történelmi növekedések voltak tapasztalhatóak [3].

A növekedést két fő tényező vezérelte, Kína további gazdasági növekedése és a bioüzemanyag előállítása. Kínában a gazdasági növekedés miatt az átlagjövedelmek is emelkedtek, ami növekvő élelmiszer keresletet eredményezett, megváltoztak az étkezési szokások. Különösen az állati termékek (hús- és tejtermékek) iránti kereslet nőtt meg, ami nagyobb állatállományt igényel, ezáltal nő a kereslet a takarmány iránt, ami a földhasználat változásával jár együtt. Ez is azt bizonyítja, hogy a 
termőföldért egyre inkább erősödik a verseny. Ezek a tényezők továbbra is befolyásolják a mezőgazdasági termékek iránti globális keresletet.

Viszont a bioüzemanyag-piacok fejlődését nagymértékben a politika és a kőolajárak határozzák meg (mint minden más terméket), ezért nehezebb előre jelezni csupán gazdasági tendenciák alapján [4].

A globális élelmiszer ellátás egyre nagyobb kihívást jelent. A „kivitelezésnél” figyelembe kell venni mind az egészségügy, élelmiszerminőség, a mezőgazdaság, az ökológia és az emberi viselkedés által okozott kihívásokat. A hangsúly azon van, hogy az élelmiszert egészséges, megfizethető és fenntartható módon állítsuk elő. Ki kell hangsúlyozni, hogy jelenleg a Földön nem a megtermelt élelmiszer mennyiségével van a probléma, hanem annak globális elosztásával és a jövedelem különbséggel. Ehhez három olyan táplálkozási probléma tartozik, amelyek párhuzamosan léteznek és részben kapcsolódnak is: az éhség - alultápláltság, a mikro tápanyag hiány és az elhízás. Ez hármas egészségügyi kockázatot jelent, hangsúlyozza az élelmiszerminőség és élelmiszerbiztonság fontosságát [5]. Nő a túlsúlyos vagy elhízott emberek száma valamint emelkedik azon fogyasztók köre is, akik magas kalóriatartalmú, de tápanyaghiányos étrenden élnek. Számtalan ember szenved mikro tápanyag-hiánytól. Itt jelenik meg a rejtett éhség fogalma, ami nem kalóriahiány, hanem a mikro tápanyag (vitamin, ásványi anyag) hiányát jelenti. Az élelmiszer- és táplálkozásbiztonság megteremtése több kihívása előtt is áll. Többek között a népesség növekedésének nyomása (2050-re több mint 9 milliárd embert prognosztizálnak), az éghajlatváltozás, más globális környezeti változás vagy a gazdasági egyenlőtlenség jelenléte [6]. Ha a történelmi eseményeket vesszük alapul, akkor az élelmiszerek globális termelése gyorsabban nőtt, mint a fogyasztás, ami az árak csökkenéséhez vezetett. Ugyanakkor, mint azt cikkében Kőmíves és Dajnoki [7] is részletezi, az élelmiszerek az egyes földrajzi régiókban eltérő áron érhetőek el az emberek számára, hiszen míg Nyugat-Európában a lakosság jövedelmének csak 15\%-át költi élelmiszerre, addig ez az arány Magyarországon 27\%, Afrikában pedig akár 60-80\%-ot is elérhet.

Egyértelmű, hogy az élelmiszerek megfizethetetlensége is migrációs nyomáshoz vezet: az emberek oda fognak vándorolni, ahol elérhető és megfizethető lesz számukra az élelem.

Az étkezési szokások változásával átalakul a mezőgazdasági termelés szerkezete. A mezőgazdasági termelés növelését azonban nem lehet a végtelenségig fokozni, ráadásul figyelembe kell venni más kritikus erőforrások - különösen a víz és a talaj - rendelkezésre álló mennyiségét, valamint kifejezetten figyelni kell az éghajlatváltozás elkerülésére és a biodiverzitás megőrzésére [8]. A biodiverzitás a gén, faj, közösség és az ökoszisztéma sokféleségére utal. Minden élőlény ide tartozik, a legprimitívebb vírusoktól a legfejlettebb növényekig és állatokig [9]. Az elmúlt 500 évben több mint 300 gerinces faj kipusztult, és még sokan vannak a kihalás szélén, ami komolyan csökkenti a bolygó élővilágának a változatosságát. A biológiai sokféleség fontos előnyöket jelent a beporzástól kezdve egészen a tápanyag-körforgásig, ami létfontosságú az emberi egészség és a gazdaság számára. A mezőgazdaság a biológiai sokféleség csökkenésének egyik fő oka [10].

Az élelmiszergazdaság az energiafogyasztás mintegy 30\%-t teszi ki, valamint az üvegházhatást okozó gázok 1/3-a is a mezőgazdasági tevékenységekhez köthető [11]. Fenntarthatóan kell fokozni a mezőgazdaság termelékenységét a növekvő kereslet kielégítése érdekében. Az élelmiszer és a mezőgazdasági termékek iránti igény 50\%-kal fog növekedni 2050-ig. A kereslet strukturális 
változását olyan tényezők befolyásolják, mint a népességnövekedés, az urbanizáció és az egy főre jutó jövedelemnövekedés. Az erőforrás-felhasználás hatékonyságát globálisan kell elérni, hogy megállítsuk és visszafordítsuk a degradálódást, valamint megfeleljünk a növekvő élelmiszer igényeknek. Az utóbbi évtized technológiai fejlődése mára lelassult. A mezőgazdaságba, a halászatba és az erdőgazdálkodásba fektetett beruházásoknak és a kutatásokra szánt összegeknek növekedniük kell a fejlődés érdekében, különösen az alacsony életszínvonalú országok területén. Ehhez előtérbe kell helyezni a fenntartható termelési rendszerek és gyakorlatok elfogadását és megismerését. Szorosan ide kapcsolódik az integrált növénytermesztés és mezőgazdaság, a fenntartható erdőgazdálkodás és a fenntartható halgazdálkodás. Ezek együttese segítheti az ökoszisztémák alkalmazkodását a klímaváltozás okozta kihívásokra helyi és globális szinten egyaránt.

A természeti erőforrások meglétét is fenntarthatóan kell biztosítani. Az előrejelzések szerint 2050-re a mezőgazdasági terület 100 millió hektárra zsugorodik [4]. Feltehetően a magasabb jövedelmű országokban a mezőgazdasági terület csökkeni fog, míg az alacsonyabb jövedelmű országokban növekedni. Valójában a mezőgazdasági terület növekedését korlátozza az a tény, hogy a még rendelkezésre álló földterülethez nehezen lehet hozzáférni az infrastruktúra hiánya vagy a piactól való távolság miatt. Továbbá az elérhető földterület csak néhány ország területére koncentrálódik. Éppen ezért a mezőgazdasági termelés élelmiszer-kereslet kielégítésének növekedése elsősorban a termelékenység és az erőforrás-felhasználás hatékonyságának javításából eredhet. A vízhiány problémája egyre több helyen jelenik meg, de az öntözés alatt álló földterületek bővülési üteme mára lelassult. A jövőbeni vízhiányt nemcsak a keresletváltozások fogják befolyásolni, hanem a rendelkezésre álló vízkészletek változásai is, amit a csapadék- és a hőmérséklet-ingadozás jelentősen befolyásol.

Az éghajlatváltozáshoz köthető természeti csapások száma nagymértékben emelkedett az elmúlt időszakban. A klímaváltozás jelentősen befolyásolja az élelmezésbiztonságot 2030-ig. A klímaváltozás hatással van az élelmiszer mennyiségére, a terméshozamra, a halállományra és az állatok egészségére. A klímaváltozást gyakran jelentős „éhség-fokozó” kockázatként tartják számon. Ennek hatására ugyanis egyes kutatások szerint 2050-re további 120 millió ember lesz alultáplált, melyből 24 millió gyerek. A becsült alultápláltak fele (60 millió fő) a szubszaharai Afrika területére koncentrálódik [3]. 2030-ra a kedvezőtlen hatások a világ legtöbb részén jelentős hozamveszteséget fognak előidézni. A szélsőséges anomáliák - aszályok, árvizek - felerősödnek és sokkal gyakoribbá válnak.

Az éhezés és a mikrotápanyag hiány mértékét csökkenteni kell vagy meg kell szüntetni a lehető legrövidebb időn belül. A világ népességének jövőbeni növekedése aránytalanul koncentrálódik azokban az országokban, ahol nem megfelelő az élelmiszerbiztonság és az élelmezésbiztonság kérdése. A jövedelem átlagos emelkedése és az urbanizáció is hatással van az étkezési szokásokra, azon belül is a gabonafélék, a tej és a húskészítmények iránti kereslet jelentős növekedésére. Az élelmiszerellátó rendszereket a modern és a hagyományos ellátási csatornák határozzák meg. Ezek a rendszerek azonban változóak, mivel számos régióban egyre inkább támaszkodnak a globális ellátási láncokra és az olyan nagyszabású elosztórendszerekre, mint a szupermarketek. De a nagy szupermarketek követelményei - az egységesség, a konzisztencia, a rendszeres kínálat és a nagy volumen miatt - 
nehézséget okozhatnak a kistermelőknek. Fogyasztói szinten a vásárlások során a vevők sokszor nem terveznek előre, a lejárati időt nem veszik figyelembe, ami élelmiszerpazarláshoz vezet.

A globalizáció számtalan előnye mellett egyre többször kell szembesülnünk a hátrányaival is. A mezőgazdaságot a határokon átterjedő állati- és növényi kártevők, betegségek veszélyeztetik. Egyes területeken nem őshonos kártevők, betegségek jelenhetnek meg, amelyhez a globalizációs robbanás jelentősen hozzájárult. Az idegen növényi kártevők és betegségek ellen hatékonyan fel kell lépni. Az élelmiszerbiztonság helyzetét tovább veszélyeztetheti az élelmiszer-feldolgozás során használt szennyezett víz, a nem biztonságos élelmiszerkezelés, a nem megfelelő tárolóeszközök, valamint a gyenge szabályázások, előírások.

A globális vízhasználat adatai alapján 1950 és 2010 között a globális háztartási vízhasználatot 390 km³-re becsülték, ami az elmúlt 60 év alatt 3,7-szeresére nőtt [12]. A vízhiány az egyik legégetőbb probléma a Földön, ezért alternatív víztakarékossági megoldások szükségesek. Az egyik legígéretesebb alternatíva a kezelt szennyvíz újrafelhasználása a mezőgazdaságban. A kezelt szennyvíz az egyik legfontosabb vízforrás a különösen száraz régiókban [11]. A fenntartható környezet védése is előtérbe kerül a megfelelően kezelt szennyvíz révén. Valójában a szennyvíz szennyező anyagai a víz forrásától függően változnak. A forrás lehet például mezőgazdasági, ipari vagy háztartási szennyvíz is. A különböző szennyvizek mikroorganizmusokat, szerves anyagokat, tápanyagokat és radioaktív anyagokat is tartalmazhatnak [13].

Az Amerikai Egyesült Államok Környezetvédelmi Hivatala és a WHO együttesen határozták meg az újrafelhasznált vizek megengedett organikus és nem organikus kemikália szintjét [14;15]. A mezőgazdasági munka során elvezetett víz számos műtrágyát és peszticid-maradványt (rovarölő-, gombaölő-, gyomirtószer), tartalmazhat különböző koncentrációkban. Az innen származó víz minőségét a sótartalom, különböző ionok mérgező nyomelemei, peszticidjei, valamint a növényi tápanyagok (pl. nitrát és a foszfátok) befolyásolják [16]. A víz és a levegőszennyezés mellett a peszticidek közvetlenül érintik az emberek és más fajok egészségét. Egyes mérgező anyagok felhalmozódnak a tápláléklánc során, és hosszú ideig fennmaradnak az élőlényekben [17].

Az ipari szennyvíz is komoly veszélyforrás, itt a víz, főként speciális kémiai összetevőkkel van tele. Az ipari szerves hulladékok gyakran biológiailag vagy hő hatására szén-dioxidra és vízre bomlanak, míg a szervetlen ipari hulladékok nem lebonthatók, csak speciális kezelések után, amelyek csökkentik a káros környezeti hatást [18]. A nem kezelt szennyvíz a levegő, az édesvíz és a talaj szennyeződésének forrása is [19].

Az éghajlatváltozás paramétereinek a változása jelentősen befolyásolja a vízforrásokat, és ezáltal az emberiség megélhetését, különösen a vízhiánnyal küzdő országokban. Mivel az édesvíz elérhetősége kulcsfontosságú a fenntartható jövő biztosítása szempontjából, kritikus kapcsolat van a vízgazdálkodás, továbbá az éghajlati és éghajlatváltozási politikák között [20]. Ez kihívást jelentő feladat, mivel számos tényezőtől függ, mint például a felmelegedés mértéke és annak következményei a hidrológiai erőforrásokra. Az előrejelzések szerint a pesszimista klímaváltozási forgatókönyvek egyre inkább valószínűbbé válnak, mivel a tervezett felmelegedés a vártnál gyorsabb ütemben halad. Ilyen körülmények között a hidrológiai erőforrások megléte létfontosságú kérdésként jelenik meg, amelyet a politikai döntéshozóknak kezelniük kell [21]. 
A világ gazdaságai egyre jobban összekapcsolódnak, a növények és az ezekből készült termékek globális áramlása egyre növekszik, ezért fontos megérteni e változások környezeti hatását. A legalacsonyabb szinteken a biológiai sokféleség függhet az élő szervezetek génjeinek szekvenciáitól. A gének DNS szakaszokból állnak, ezek a szekvenciák a gének által kódolt fehérjék. A mezőgazdasági ökoszisztémákat úgy módosították, hogy már tápanyagokban gazdag monokultúrákká váltak, így lehetővé tették egyes növények termesztését a korábban alkalmatlan körülmények között [22]. Például a tejtermelés ma már gyakori a mediterrán éghajlaton, és a saláta az arizonai száraz éghajlaton is termeszthető [23]. A hagyományos mezőgazdasági tevékenységet eddig a magas költségek és a természeti környezet súlyos megterhelése jellemezte. Az élelmiszertermelés növelése érdekében a kutatók új, magasabb terméshozamú fajtákat állítanak elő, amelyek gyorsabban nőnek, de egyre nagyobb mértékben veszik igénybe a talaj tápanyagkészletét. Így több nitrogén- és foszfortartalmú műtrágyát alkalmaznak, nagyobb területen termesztenek és öntöznek, de ezzel arányosan a peszticidek használata is jelentősen megnőtt [24]. A gyakran alkalmazott növényvédőszerekkel szemben a kártevők és kórokozók egyfajta rezisztenciát alakítanak ki.

Ezen kívül a legtöbb rovarölő nem kizárólag egy adott fajra, hanem gyakran más, nem kártevő gerinctelenekre is hat, továbbá a kártevők természetes ellenségeit is megölheti, amelyeknek fontos szerepe lenne az adott kártevő természetes kontrolljában [24].

2011-ben az ENSZ-ben az agroökológiát tekintették a fenntartható gazdálkodás kulcsának. Az agroökológia az agronómia és az ökológia egyesítésével fenntartható mezőgazdasági ökoszisztémákat hoz létre, elérve ezt olyan természetes folyamatok visszaállításával és javításával, mint például a tápanyagok és energia újrahasznosítása, a növények és állatok diverzifikálása. Az agroökológiai módszerek - mint például a biológiai védelem megőrzése - növelhetik a mezőgazdasági ökoszisztéma értékét, miközben csökkentik a peszticidek, műtrágyák és üzemanyagok felhasználásából származó negatív hatásokat [25].

A modern mezőgazdasági gyakorlatok - ideértve a talajművelést és a hagyományos rovarölő szerek intenzív használatát - nagymértékben kapcsolódnak a biológiai sokféleség csökkenéséhez az agrárökoszisztémákban. A földterületek mezőgazdasági célú felhasználása nagyon korlátozza a gének áramlását az egyes fajok között. Ha egy állatfaj egyede képtelen átjutni a mezőgazdasági területeken, akkor a populációk elszigetelődnek, így tovább csökken az egyedszám és populációk életképessége [26]. A talajművelés a mezőgazdasági táj gyakori átformálásához vezet és növeli a talajeróziókból származó problémákat.

Az elmúlt közel 40 évben az energiatermelés megduplázódott. A megújuló energiaforrások hozzájárulása 19\%-ra tehető. A megújuló energiaforrások közül 10,3\%-ot a „modern” energiaforrások, mint a szél-, nap-, víz-, geotermikus-energia, bioüzemanyagok, stb. képviselnek. A hagyományos biomassza 8,9\%-ot tesz ki [27]. A hagyományos biomassza kétharmadát - tűzifa - fütésre és főzésre használják. A biomasszából származó energiafelhasználás 88\%-át az erdészetek adják, amiből a tűzifa 68\%-ot, a faszén 10\%-ot, a fahulladék és a pellet együttesen 2,5\%-ot tesz ki. A bioüzemanyag ma a globális üzemanyag-fogyasztás alig 4\%-át és a megújuló energia-előállítás mintegy $6 \%$-át és teszi ki [28]. A modern bioenergia-termelésben a bioüzemanyag-gyártás, azért játszik fontos szerepet, mert a kőolaj több mint 50\%-át a közlekedési szektor használja fel, ahol a kőolajon alapuló üzemanyag- 
felhasználás aránya 93\%. A világon közlekedő 1,1 milliárd személygépkocsi száma 2040-re várhatóan 2,0 milliárd darabra emelkedik [29]. A közlekedési szektor várható energiaigényének meghatározása igen sok bizonytalansági tényezőt rejt magában, ami befolyásolja a bioüzemanyagok felhasználását is. A bioüzemanyagok így egyfajta versenytársként jelennek meg az élelmiszer- és takarmánynövényekkel szemben a termőföldért folytatott küzdelemben. A globális végső energiafogyasztás 1971 óta több mint kétszeresére nőtt. A legnagyobb fogyasztó továbbra is 37\%-os részesedéssel az ipar, a közlekedés 28\%-kal, a lakossági fogyasztás pedig 23\%-ot tett ki. A mezőgazdaság és az erdészet viszont csupán 2\%-os arányt képviselt a végső fogyasztásból. A kőolaj, szén és földgáz együttesen 81\%-ot, a megújuló energiaforrások 14\%-ot és a nukleáris energia 5\%-ot tett ki [27]. A „modern” megújulók: a szél-, nap-, víz-, geotermikus-energia, bioüzemanyagok 14\%-t tettek ki. A megújuló energiát 90-92\%-át fútésre, 5\%-át közlekedésre, 3\%-át villamos energiatermelésre használják világszerte. A tradicionális biomassza kétharmadát (túzifa) még mindig főzésre és fütésre használják fel pazarló módon [29].

\section{Következtetések és javaslatok}

Véleményem szerint - mint minden más szektorban - a technológia és a tudás fejlődése a megoldás a globális problémák megfékezésére vagy megszüntetésére. Az agrárium területén is megállíthatatlanul előretört a technikai vívmányok fejlődése, azonban ez a tudás önmagában nem elegendő, ha az ember nem hajlandó „fejben” is megváltozni. A jelenlegi fejlettség önmagában már képes lenne kiszolgálni az emberiség igényét, de a fő problémát még ma is - mióta az ember létezik - az egyenlőtlen erőforrás elosztás jelenti. Ezen a problémán sokat segít a technikai fejlődés, de „a tudományos eredmények igazából csak akkor szolgálják az emberiség üdvét, ha minél szélesebb tömegek életét teszik elviselhetőbbé" Ungvári Tamás (2011) szavaival élve. Krzysztof Borun (1960) szavai alapján én is hasonlóan vélekedem arról, hogy „A tudományos haladás nem veszte az emberiségnek, hanem utolsó reménye! Ha megmentheti valami a világot a pusztulástól, akkor az csak a tudomány lehet!"

A FAO becslése szerint évente a globális terméshozam 20-40\%-a a kártevők és a betegségek miatt elvész, a közel 2 millió tonna évi növényvédőszer használata ellenére [4]. Így az egyik fontos lépés az előbb említettek erőteljes csökkentése. Az intelligens eszközök, mint például a robotok és a drónok, lehetővé tehetik a mezőgazdasági termelők számára, hogy a mezőgazdasági veszélyeket korábban és gyorsabban azonosítsák be, lehetővé téve a gyorsabb kártevő észlelést. A technológia fejlődésének köszönhetően egyre hatékonyabbá válik a kártevők kiküszöbölése.

A friss gyümölcsök és zöldségek egyre inkább a magas minőség megőrzésével és a költségek minimalizálásával maradhatnak versenyben. Ha a betakarítást az optimális gyümölcsérésre ütemezhetjük, akkor gazdasági és minőségi előnyöket nyerhetünk. Ezt segítheti egy szenzor, amit közvetlenül a gyümölcsön helyezhetünk el és az okos telefonunkon futtatható alkalmazással figyelhetünk, azonban ez még elég költséges megoldás. Az alkalmazás a termesztők által készített gyümölcsök fotóit használja a növekedési ráta kiszámításához. A technikai vívmányokat nem csak növényeken, de állatok esetében is alkalmazhatjuk. Az emberi nyomonkövetés és a fitnesz segédeszközök nyomán a szarvasmarháknál használhatunk úgynevezett „okos nyakörveket”. Ezeket megfigyelés céljából 2010 óta használják skóciai kutatók. A nyakörv figyelemmel kíséri az ivarzást a 
mozgás nyomon követésével - a tehenek többet mozognak, ha ivarzanak - ekkor a készülék figyelmezteti a gazdálkodókat arra, amikor egy tehén készen áll a párzásra, üzenetet küldve laptopjára vagy okostelefonjára. A kamerák időben felismerhetnek bizonyos betegségeket. Belga kutatók kifejlesztettek egy kamera rendszert a broiler csirkék keltetési megfigyelésére. A broiler csirkék viselkedésének megfigyelése korai figyelmeztetést adhat a problémás esetek 90\%-ban [30].

A földművesek legértékesebb erőforrása a termőföld. A talaj egy komplex rendszer, melyben számos élettani folyamat zajlik. A tápanyagellátás szempontjából számos biológiai folyamatot figyelembe kell vennünk, mint például a tápanyagok felvehetősége vagy a talajban élő mikroorganizmusok.

A robotika és az automatizált gépesítés ezen segíthet. Német tudósok kifejlesztettek egy autó méretű robotot, ami mérni tudja a talajminőség különböző mutatóit szenzorok és modulok alkalmazásával. Ideértve a nedvességérzékelőt és a penetrométert, amelyet a talaj tömörödésének értékelésére használnak.

\section{Összefoglalás}

A mezőgazdasági ágazatnak azzal a kihívással kell szembenéznie, hogy miként növelje a hatékonyságot - a korlátozott földterület és a vízkészlet ellenére - úgy, hogy élelmiszert és energiát biztosítson az egyre növekvő népesség számára. A növénytermesztés filozófiája szerint az adottságoknak és a célnak megfelelően történik a termelés. Ebben az összefüggésrendszerben megjelenik a növénytermelési folyamatok optimalizálása mellett az erőforrások racionális felhasználása is. A már meglévő, "modern" technológiákat precízen kell alkalmazni, ami elkötelezettséget követel a termelés minden szereplőjétől. A fenntarthatóság eszméjében minden újítás, előremutató megoldás fontos, amely az előállított biztonságos élelmiszermennyiséghez hozzájárul és szolgálja a társadalmi fenntarthatóságot is. A növekvő jövedelmek hatására változnak a táplálkozási szokások, növekvő igény mutatkozik a magas feldolgozottságú mezőgazdasági termékek iránt. Széles körű kutatások folynak arról, hogy miként lehetne a globális problémákat megoldani mezőgazdasági és biológiai szempontból egyaránt. A globalizációnak köszönhetően a mezőgazdaság egyszerre lát el élelmezési és energetikai funkciót. A kulcs, hogy biztosítsuk a bolygó természetes fenntartóképességét, úgy, hogy ellássuk élelemmel a növekvő népességet, miközben csökkentjük a mezőgazdasági termelés környezeti lábnyomát, jólétet teremtve a jelen és jövő generációi számára is.

A kutatások jelentősen hozzájárulnak a mezőgazdaság és a környezet közötti kapcsolatot érintő gazdasági döntések megértéséhez. Ez a fenntarthatóbb mezőgazdaság támogatására irányuló politikai ösztönzők kialakításához vezet. A termelés során a fogyasztókkal együtt kell törekedni a fenntartható környezet elérésére. A jövőben támaszkodni kell a talajminőséggel, az éghajlattal, a földhasználattal kapcsolatos adatokra és a fenntartható földhasználatra irányuló stratégiák kialakítására. Az utóbbi években megnövekedett azon kutatások száma, amelyek integrált megközelítésben vizsgálják a globális kihívások összefüggését, természetesen az előbb említett adatok felhasználásával. 


\section{Hivatkozások:}

[1] FAO (2011) Looking ahead in world food and agriculture: perspectives to 2050. In: P. Conforti. (szerk.): Agricultural Development Economics Division Economic and Social Development Department Food and Agriculture Organization of the United Nations, Paris. p. 539 (ISBN 97892-5-106903-5) http://www.fao.org/docrep/014/i2280e/i2280e.pdf

[2] J. Popp - J. Oláh - J. Szenderák - M. Harangi-Rákos (2017) A marhahús előállítás nemzetközi és hazai piaci kilátásai. Állattenyésztés és Takarmányozás, 66 (4) pp. 276-299.

[3] FAO (2016) Food outlook

[4] FAO (2017) The future of food and agriculture, Trends and challenges

[5] R. Horton - S. Lo (2013) Nutrition: a quintessential sustainable development goal. Lancet

[6] J. Pretty et al. (2010) The top 100 questions of importance to the future of global agriculture. International Journal of Agricultural Sustainability, 8 pp. 219-236.

[7] P. M. Kőmíves - K. Dajnoki (2016) Labour market integration issues related to migrants arriving to Hungary. Annals of the University of Oradea Economic Science, 25 (1) pp. 363-373.

[8] EASAC policy report (2017)

[9] E. D. Fountain - S. D. Wratten (2013) A narrative of agriculture and biodiversity loss. BioProtection Research Centre, Lincoln University, New Zeland.

[10] A. Chaudhary - T. Kastner (2016) Land use biodiversity impacts embodied in international food trade. Global Environmental Change, 38 pp. 195-204. DOI: 10.1016/j.gloenvcha.2016.03.013

[11] K. M. Gothandam - R. Shivendu - D. Nandita - R. Chidambaram - E. Lichtfouse (2017) Nanotechnology, Food Security and Water Treatment, Environmental Chemistry for a Sustainable World. ISBN: 978-3-319-70165-3

[12] M. Flörke - E. Kynast - I. Barlund - S. Eisner - F. Wimmer - J. Alcamo (2013) Domestic and industrial water uses of the past 60 years as a mirror of socio-economic development: a global simulation study. pp. 144-156.

[13] M. Henze (2002) Wastewater, volumes and composition. 3rd edition. Springer, Berlin/Heidelberg. pp. 11-42.

[14] U.S. Environmental Protection Agency (2012) Guidelines for water reuse, 600/R-12/618. U.S. EPA, Washington, DC

[15] WHO, World Health Organization (2006) Guidelines for the safe use of wastewater, excreta and greywater, volume 2: wastewater use in agriculture. World Health Organization, Geneva.

[16] K. Tanji - N. C. Kielen (2002) Agricultural drainage water management in arid and semi-arid areas. FAO irrigation and drainage paper 61. Food and Agriculture Organization of the United Nations, Rome.

[17] K. A. Kidd - D. W. Schindler - D. C. G. Muir - W. L. Lockhart - R. H. Hesslein (1995) High concentrations of toxaphene in fishes from a subarctic lake. Science, 269 (5221) pp. 240-242.

[18] J. F. Artiola (2006) Industrial and municipal solid waste treatment and disposal. Environmental \& pollution science, 2nd edition. Elsevier Inc, California. pp. 415-428.

[19] T. A. Elbana -M. A. Ramadan - H. M. Gaber - M. H. Bahnassy - F. M. Kishk - H. M. Selim (2013) Heavy metals accumulation and spatial distribution in long term wastewater irrigated soils. 
[20] A. G. Koutroulis - L. V. Papadimitriou - M. G. Grillakis - I. K. Tsanis - K. Wyser - R. A. Betts (2017) Freshwater vulnerability under high end climate change. A pan-European assessment. Science of the Total Environment.

[21] L. V. Papadimitriou - A. G. Koutroulis - M. G. Grillakis - I. K. Tsanis (2016) High-end climate change impact on European run off and low flows: exploring the effects of forcing biases.

[22] D. Tilman (1999) Global environmental impacts of agricultural expansion: The need for sustainable and efficient practices. Proceedings of the National Academy of Sciences (USA) 96 pp, 5995-6000.

[23] M. S. Swaminathan (2012) Sustainable development: Twenty years after Rio. International Consultation on Twenty years of Rio: Biodiversity-Development-Livelihoods, Chennai, India.

[24] M. Calonne - J. Fontaine - D. Debiane - F. Laruelle - A. Grandmougin - A. Lounes-Hadj Sahraoui (2011) Side effects of the sterol biosynthesis inhibitor fungicide, propiconazole, on a beneficial arbuscular mycorrhizal fungus. Communications in Agricultural and Applied Biological Sciences, 76 pp. 891-902.

[25] M. Jonsson - S. D. Wratten - D. A. Landis -G. M. Gurr (2008) Recent advances in conservation biological control of arthropods by arthropods. Biological Control, 45 pp. 172-175.

[26] B. Lanza - S. Dietzd - T. Swansone (2017) The Expansion of Modern Agriculture and Global Biodiversity Decline: An Integrated Assessment. Ecological Economics, 144 pp. 260-277.

[27] M. Harangi-Rákos - J. Popp - J. Oláh (2018) A biomassza energetikai és egyéb célú felhasználása. Magyar Energetika, 25 (2) pp. 12-22.

[28] M. Harangi-Rákos - J. Popp - J. Oláh (2017) A megújuló energia termelésének kilátásai az EU energiafogyasztásában. Energiagazdálkodás 58 (6) pp. 19-25.

[29] J. Popp - S. Kot - Z. Lakner - J. Oláh (2018) Biofuel use: peculiarities and implications. Journal of Security and Sustainability Issues, 7(3) pp. 477-493.

[30] A. King (2017) The future of agriculture. Nature, 544 (7651) S21-S23. 